\title{
Physico - chemical treatment of Bukit Tagar sanitary landfill leachate using P-Floc775 and Ferric chloride
}

\author{
Agamuthu, P.* and Said Nasser Ali Al - Abdali
}

Institute of Biological Sciences, Faculty of Science, University of Malaya,50603 Kuala Lumpur,Malaysia.

*agamuthu@um.edu.my (corresponding author)

Received in $15^{\text {th }}$ May 2008, accepted in revised form $20^{\text {th }}$ July 2009.

\begin{abstract}
Bukit Tagar Sanitary landfill leachate was characterized and then treated with ferric chloride and P-Floc775, individually. The raw leachate contained high concentration of $\mathrm{BOD}_{5}(27000$ $\mathrm{mg} / \mathrm{L}), \quad \mathrm{COD}(59000 \mathrm{mg} / \mathrm{L}), \mathrm{NH}_{3}-\mathrm{N}(4300 \mathrm{mg} / \mathrm{L}), \mathrm{Pb}(15.15 \mathrm{mg} / \mathrm{L}), \mathrm{Al}(15.75 \mathrm{mg} / \mathrm{L}), \mathrm{Zn}(17.55$ $\mathrm{mg} / \mathrm{L}), \mathrm{Fe}(84.3 \mathrm{mg} / \mathrm{L}), \mathrm{Cu}(10.95 \mathrm{mg} / \mathrm{L}), \mathrm{Cd}(11.25 \mathrm{mg} / \mathrm{L})$ and As $(3.6 \mathrm{mg} / \mathrm{L})$. All these parameters exceeded the Malaysian regulatory standard limit of EQA 1974 (Standard A and B). Leachate treatment was optimum with $2 \mathrm{~g} / 500 \mathrm{ml} \mathrm{FeCl}$ at $\mathrm{pH} 7$ and mixing speed $100 \mathrm{rpm}$. It was able to reduce about $100 \%$ of $\mathrm{Cd}, \mathrm{Pb}$ and $\mathrm{Cu}$ to below the Environmental Quality (Sewage and Industrial Effluent) Regulation Standard B while Zn was reduced by $89 \%$ but was still above standard B. The optimum for P-Floc775 was $2 \mathrm{ml} / 500 \mathrm{ml}, \mathrm{pH} 7$ and mixing speed $90 \mathrm{rpm}$. Maximum removal of $\mathrm{Cd}$ and $\mathrm{Cu}$ was $100 \%$ which was below the Environmental Quality Regulation Standard B requirements. P-Floc775 was able to reduce $\mathrm{Pb}$ and $\mathrm{Zn}$ by $82 \%$ and $88 \%$, respectively, which were still above Standard B. Further integrated leachate treatment is recommended to achieve the EQA regulation limits.
\end{abstract}

ABSTRAK Ciri-ciri larut lesapan dari tapak pelupusan sanitari Bukit Tagar telah dikaji dan dirawat dengan ferric klorida dan P-Floc775 secara berasingan. Larut lesapan mentah tersebut mengandungi kepekatan yang tinggi untuk $\mathrm{BOD}_{5}(27000 \mathrm{mg} / \mathrm{L}), \mathrm{COD}(59000 \mathrm{mg} / \mathrm{L}), \mathrm{NH} 3-\mathrm{N}(4300 \mathrm{mg} / \mathrm{L}), \mathrm{Pb}(15.15$ $\mathrm{mg} / \mathrm{L}), \mathrm{Al}(15.75 \mathrm{mg} / \mathrm{L}), \mathrm{Zn}(17.55 \mathrm{mg} / \mathrm{L}), \mathrm{Fe}(84.3 \mathrm{mg} / \mathrm{L}), \mathrm{Cu}(10.95 \mathrm{mg} / \mathrm{L}), \mathrm{Cd}(11.25 \mathrm{mg} / \mathrm{L})$ dan As (3.6 mg/L). Semua parameter tersebut melebihi tahap piawai Malaysia (EQA' 1974, Standard A dan B). Rawatan larut lesapan adalah optimum dengan $2 \mathrm{~g} / 500 \mathrm{ml} \mathrm{FeCL}_{3}$ pada $\mathrm{pH} 7$ dan kelajuan campuran 100 rpm. $\mathrm{FeCl}_{3}$ dapat mengurangkan sebanyak $100 \% \mathrm{Cd}, \mathrm{Pb}$ dan $\mathrm{Cu}$ sehingga di bawah Piawai $\mathrm{B}$, Akta Kualiti Alam Sekitar (Kumbahan dan Buangan Industri). Sementara Zn dapat dikurangkan sebanyak 89\% tetapi masih melebihi Piawai B. Optimum untuk P-Floc775 adalah 2ml/500ml, pH 7 dan kelajuan campuran $90 \mathrm{rpm}$. Tahap maksima penyingkiran $\mathrm{Cd}$ dan $\mathrm{Cu}$ adalah $100 \%$ di mana ia adalah di bawah keperluan Pengawalan Piawai B, Kualiti Alam Sekitar. P-Floc775 masing-masing dapat mengurangkan $\mathrm{Pb}$ dan $\mathrm{Zn}$ sebanyak $82 \%$ dan $88 \%$, di mana ia masih melebihi Piawai B. Rawatan larut lesapan sepadu selanjutnya dicadangkan untuk mencapai linkungan piawai pengawalan EQA.

(Keywords: chemical treatment, landfill leachate, P-Floc775)

\section{INTRODUCTION}

Rapid economic growth in Malaysia over the last fifteen years has enhanced the development process of the country. Many changes have taken place due to urbanization and industrialization. Rapid development, an increase in population, rural-urban migration, affluence and the rate of consumption have brought about an increase in waste generation and pollution which has badly affected man and environment. Malaysia has an average waste generation of 0.7 to $1.3 \mathrm{~kg}$ per capita and most of these wastes were disposed at 260 landfills through the country [1]. These landfills received around 8 million tonnes/yr of municipal solid waste [2]. Currently, around 31,000 tonnes of municipal solid waste is produced in Malaysia every day and the MSW is highly heterogeneous [3]. The main component is organic kitchen waste which forms about $46 \%$ while plastic is $14 \%$.

Landfill leachate is generated when rainwater mixes with the waste in a landfill [4]. It can cause great environmental degradation if it gets into groundwater, because it has large concentration of organic matter (both biodegradable and non-biodegradable carbon), ammonia-nitrogen, heavy metals, and 
chlorinated organic and inorganic salts. However, some of these pollutants can be degraded by microorganisms [5], while others may not be degraded and may persist in the landfill for long period. It is estimated that the total volume of leacheate generated in Malaysia is 3.0 million per day. The leacheate exhibits extremely high BOD and COD values ramping from 2000 to $30,000 \mathrm{mg} / \mathrm{L}$ for BOD and 300 to $60,000 \mathrm{mg} / \mathrm{L}$ for COD [3].

Treatment of leachate is an important aspect in municipal waste management system. This is so because of the high ratio of COD/BOD which is 2.2 and ammonia nitrogen $\left(\mathrm{NH}_{3}-\mathrm{N}\right)$ at 0.43 , which posed major difficulties in biological treatment of leachate [6]. The best method of leachate treatment depends on the characteristics of the leachate. There are different methods of treatment of leachate, one of which is the physical - chemical process [7]. In most cases a single technology is not sufficient to achieve permitted level of pollution decrease [8]. Treatment can be a combination of two or more methods such as bio-physicochemical processes $[9,10,11,12]$. This combination is popularly used to achieve excellent leachate treatment efficiency [13].

In Malaysia only $10 \%$ of the landfills are sanitary while the remaining $90 \%$ are either modified dumps or illegal dumping sites. Leachate treatment technique varies with the level of the landfill but is most cases it is still very rudimentary. In Bukit Tagar landfill total integrated system is used, where Physical, Chemical and Biological treatments are in place. Additionally phyto-remediation is employed to enhance the effluent quality to Malaysian standards.

Physiochemical treatments exist for not only removing refractory substances from the leachate, but also, it is counted as a refining prestep which is required before biological treatment of leachate [14]. These methods are like those used to reduce COD, decrease suspended solids, colloidal particles, floating material, heavy metals, suspended solids and color [15]. For example coagulation and flocculation is used to remove heavy metals and non-biodegradable organic compounds from landfill leachate $[16,17]$. In coagulation, the first step destabilizes the particle's charges. Coagulants have opposite charges to those of suspended solids and the coagulants are used in the leachate in order to defuse the negative charges on dispersed solids, which are not settled, like color-producing organic substances and clay [18]. When the charge is neutralized, the small particles which are suspended stick together and increase the size of the particles. Sometimes not all suspended particles are neutralized because the coagulant used is not sufficient [18]. The next step after coagulation is flocculation which effects in the moving particles that are not fixed, to form large flocks so that it can settle down faster.

This study concentrates on leachate generated from Bukit Tagar Sanitary landfill, which is located $50 \mathrm{~km}$ from Kuala Lumpur. Bukit Tagar Sanitary landfill received around 1600 tonnes of MSW per day and generated $500-700 \mathrm{~m}^{3}$ of leachate daily. The landfill has high density polyethylene membrane as the base liner, and a multilayer system is used to ensure complete separation of waste from the ground. The landfill (Bukit Tagar Sanitary Landfill) is 3years old and is 700 acres foot print with 1000 acres buffer zone use, as well as, final cover of 1meter thickness. The waste disposal here is highly mixed municipal solid waste which is not source separated.

The aim of this study was to establish the leachate characteristics and to investigate the effectiveness of P-Floc775, and $\mathrm{FeCl}_{3}$, as a coagulant (Table 1) to treat the leachate. The study includes physical and chemical characterization and coagulation at different concentration of coagulants, different $\mathrm{pH}$ and different mixing speed. This will form the pretreatment before the leachate undergoes more physical and biological treatments.

\section{MATERIALS AND METHODS}

Raw leachate samples taken over a period of 5months from Bukit Tagar landfill was analysed to establish the mean characteristics of the leachate. Since Malaysia does not have distinct seasonal variations, the sampling period represents the drier months as well as the monsoon season.

The leachate analysis includes:

1. $\mathrm{pH}$ and conductivity, measured using a $\mathrm{pH}$ and conductivity probe ( Hanna Model, No. 8033).

2. Total suspended solid (TSS), and Colour, determined by using Spectrophotometer, HACH Model (DR/4000).

3. $\mathrm{BOD}_{5}, \mathrm{COD}$, and Total-N were analysed according to Standard Methods APHA, AWWA, and WEF [19]. 
4. Heavy metals were determined using digested leachate using Inductively Coupled Plasma Optical Emission Spectrometry (ICP-OES).

Table 1. Characteristics of the Coagulants used
Two types of coagulants were used. P-Floc 775 is a relatively new chemical which has not been tested, whereas $\mathrm{FeCl}_{3}$ is a well tested coagulant and it serves as the comparable standard.
Coagulant

Ferric chloride

\section{Characteristics}

Iron (III) chloride is called ferric chloride with the formula $\mathrm{FeCl}_{3}$. It is purple-red and dark green colour. When it is dissolved in water it gives off heat. Iron (III) chloride boils at around $315^{\circ} \mathrm{C}$ and it has a relatively low melting point. $\mathrm{FeCl}_{3}$ is used in sewage treatment and drinking water production.

P-Floc775 is a cationic, polyquatenary amine in water solution. It is a liquid cationic polyelectrolyte of medium molecular weight. It works as a primary coagulant aid in water clarification and as dewatering aid in industrial waste sludge. P-Floc775 affects agglomeration of suspended solids through a combination of various mechanisms such as neutralization and absorption.

\section{Jar Test Trials}

1. Six - paddle flocculator from Stuart's scientific (flocculator SW1) was used.

2. $500 \mathrm{~mL}$ leachate samples were coagulated using either $\mathrm{P}$ - Floc775 (0-12 mL/500mL), or Ferric chloride $(0-12 \mathrm{~g} / 500 \mathrm{~mL})$ as coagulant (Table 1).

3. After establishing the optimum concentration, effect of $\mathrm{pH}$ was tested at a $\mathrm{pH}$ the range of 4 to 10 , for both coagulants.

4. After determining the optimum $\mathrm{pH}$, effect of mixing speed was carried out.

5. The supernatant in all studies were collected and analysed.

All tests were carried out in 4 replicates and the mean results used for discussion.

\section{RESULTS AND DISCUSSION}

Raw leachate from Bukit Tagar sanitary landfill (Table 2) contains high concentrations of most of the parameters. The $\mathrm{BOD}_{5}$ and $\mathrm{COD}$ values were $27000 \mathrm{mg} / \mathrm{L}$ and $59000 \mathrm{mg} / \mathrm{L}$, respectively and this high readings indicate that there are organic materials in the leachate which are highly biodegradable The ratio of $\mathrm{BOD}_{5} / \mathrm{COD}$ of raw leachate was about 2.2 and this value shows that the organic material in the leachate is easily biodegradable [19]. The values of $\mathrm{BOD}_{5}$ and $\mathrm{COD}$ can be considered very high compared to the Sewage and Industrial Effluent Regulation 1979 Standard B requirements [20]. The allowable concentration of $\mathrm{BOD}_{5}$ and $\mathrm{COD}$ Mn $(17.85 \mathrm{mg} / \mathrm{L})$, and Se $(1.65 \mathrm{mg} / \mathrm{L})$ and all parameters measured also exceeded the regulatory standard limit of EQA 1974 in the regulation is $50 \mathrm{mg} / \mathrm{L}$ and $100 \mathrm{mg} / \mathrm{L}$, respectively.

The $\mathrm{pH}$ of the leachate sample was 6.6 and this indicates that the landfill is in an acid phase. The acid $\mathrm{pH}$ is caused by high production of volatile fatty acids and the high partial pressure of $\mathrm{CO}_{2}$ [19].

Leachate contains high concentrations of colour 15300 ADMI, total suspended solid (TSS) (13.5 $\mathrm{mg} / \mathrm{L}$ ), and ammonia due to the decomposition of waste mass. The high level of $\mathrm{NH}_{3}-\mathrm{N}$ (4300 $\mathrm{mh} / \mathrm{L}$ ) may be due to the decomposition of nitrogenous substances [9], which also indicates that the landfill is in an acidic phase [19]. The leachate also shows high turbidity (3600 FAU) and Suspended Solids as a consequence of organic and inorganic solids present. The presence of high salt concentrations in the leachate are due to the large amount of garbage (food waste) disposed in to the landfill.

Leachate from Bukit Tagar sanitary landfill (Table 2) contain high concentration of heavy metals such as $\mathrm{Pb}(15.15 \mathrm{mg} / \mathrm{L}), \mathrm{Al}(15.75$ $\mathrm{mg} / \mathrm{L}), \mathrm{Zn}(17.55 \mathrm{mg} / \mathrm{L}), \mathrm{Fe}(84.3 \mathrm{mg} / \mathrm{L}), \mathrm{Cu}$ $(10.95 \mathrm{mg} / \mathrm{L}), \mathrm{Cd}(11.25 \mathrm{mg} / \mathrm{L})$ and As $(3.6$ $\mathrm{mg} / \mathrm{L})$ and all parameters measured exceeded the regulatory standard limit of EQA 1974 (Standard A and B) [20]. This leachate has also high amount of $\mathrm{Ca}(397.8 \mathrm{mg} / \mathrm{L}), \mathrm{K}(764.4$ $\mathrm{mg} / \mathrm{L}), \mathrm{Na}(803.55 \mathrm{mg} / \mathrm{L}), \mathrm{Mg}(29.1 \mathrm{mg} / \mathrm{L})$, (Standard A and B)[20] . Sodium is a principle alkalinity metal which tends to stay in solution and is not subject to attenuation. The main 
reasons for the presence of $\mathrm{Na}$ in the leachate are the wide use of $\mathrm{Na}$ salts in industry and domestic activity (paper, soap, etc) [19]. Potassium is released during refuse decomposition and the main source of $\mathrm{K}$ is plant material and discarded food [19], which is the main component of Malaysian MSW.

The presence of heavy metals in the leachate is due to industrial waste and household nonhazardous waste [21]. Heavy metals if not removed, could cause serious consequences to human beings and the environment. Heavy metals can accumulate in the biological tissues of the body and cause serious diseases such as neurotoxic effects, renal failure (lead), genetic anomalies and cancer risk (cadmium, arsenic). This indicates clearly that need for pretreatment of leachate prior to biological treatment [22].
Some general observations can be made when comparing the Bukit Tagar Landfill leachate with other Malaysian landfill leachate data. For example leachate from Bukit Tagar sanitary landfill and the Taman Beringin Landfill (Table 2) was found to be different. The BOD and COD in Bukit Tagar landfill were $27000 \mathrm{mg} / \mathrm{l}$, $59000 \mathrm{mg} / \mathrm{l}$, respectively which were higher than the BOD and COD in Taman Beringin landfill at $560-1520 \mathrm{mg} / \mathrm{l}, \quad 2050-5230 \mathrm{mg} / \mathrm{l}$, respectively. This difference is due to the landfills since BTSC is younger than Taman Beringin Landfill. However, heavy metal concentration in the Taman Beringin Landfill such as $\mathrm{Mg}, \mathrm{Na}$ and $\mathrm{K}$ was higher while the concentration of $\mathrm{Ca}$ and $\mathrm{Fe}$ in the Bukit Tagar landfill. This could be due to the type of waste disposed, and the phase of the landfill or degradation stage of waste.

Table 2. Characteristics of raw leachate from Bukit Tagar sanitary landfill

\begin{tabular}{|c|c|c|c|c|c|}
\hline \multirow[t]{2}{*}{ PARAMETER } & \multirow[t]{2}{*}{ UNIT } & \multirow{2}{*}{$\begin{array}{c}\text { Bukit Tagar } \\
\text { Landfill } \\
\text { Leachate }\end{array}$} & \multirow{2}{*}{$\begin{array}{c}\text { Taman } \\
\text { Beringin } \\
\text { Landfill }^{*}\end{array}$} & \multicolumn{2}{|c|}{$\begin{array}{c}\text { EQA } 1974 \\
\text { STANDARD }\end{array}$} \\
\hline & & & & $\mathbf{A}$ & B \\
\hline Temperature & ${ }^{\circ} \mathrm{C}$ & $29^{\circ} \mathrm{C}$ & - & 40 & 40 \\
\hline $\mathrm{pH}$ & - & 6.6 & $8.07-8.5$ & $6.0-9.0$ & $5.5-9.0$ \\
\hline BOD $_{5}$ at $20^{\circ} \mathrm{C}$ & $\mathrm{mg} / \mathrm{l}$ & 27000 & $560-1520$ & 20 & 50 \\
\hline COD & $\mathrm{mg} / \mathrm{l}$ & 59000 & 2050-5230 & 50 & 100 \\
\hline Total Solid, TS & $\mathrm{mg} / \mathrm{l}$ & 1719 & $1380-2070$ & N.A. & N.A. \\
\hline $\mathbf{N H}_{3}-\mathbf{N}$ & $\mathrm{mg} / \mathrm{l}$ & 4300 & - & 50 & 100 \\
\hline Turbidity & FAU & 3600 & - & N.A. & N.A. \\
\hline Conductivity & $\mu^{5} / \mathrm{cm}$ & 670 & $12.6-34.6$ & N.A. & N.A. \\
\hline Salinity & $(\%)$ & 0.3 & - & N.A. & N.A. \\
\hline Colour & ADMI value & 15300 & - & - & - \\
\hline Cadmium $(\mathrm{Cd})$ & $\mathrm{mg} / \mathrm{l}$ & 11.25 & - & 0.01 & 0.02 \\
\hline Arsenic (As) & $\mathrm{mg} / \mathrm{l}$ & 3.6 & & 0.05 & 0.1 \\
\hline Lead (pb) & $\mathrm{mg} / \mathrm{l}$ & 15.15 & - & 0.01 & 0.5 \\
\hline Zinc (Zn) & $\mathrm{mg} / \mathrm{l}$ & 17.55 & - & 1.0 & 1.0 \\
\hline Copper $(\mathbf{C u})$ & $\mathrm{mg} / \mathrm{l}$ & 10.95 & - & 0.2 & 1.0 \\
\hline Aluminium (Al) & $\mathrm{mg} / \mathrm{l}$ & 15.75 & & N.A. & N.A. \\
\hline Calcium (Ca) & $\mathrm{mg} / \mathrm{l}$ & 397.8 & $63-166$ & N.A. & N.A. \\
\hline Potassium (K) & $\mathrm{mg} / \mathrm{l}$ & 764.4 & $1660-1940$ & N.A. & N.A. \\
\hline Iron $(\mathrm{Fe})$ & $\mathrm{mg} / \mathrm{l}$ & 84.3 & $7-9$ & 1.0 & 5.0 \\
\hline Sodium $(\mathrm{Na})$ & $\mathrm{mg} / \mathrm{l}$ & 803.55 & $4200-5640$ & N.A. & N.A. \\
\hline Manganese (Mn) & $\mathrm{mg} / \mathrm{l}$ & 17.85 & - & 0.2 & 1.0 \\
\hline Selenium (Se) & $\mathrm{mg} / \mathrm{l}$ & 1.65 & - & N.A. & N.A. \\
\hline Magnesium (Mg) & $\mathrm{mg} / \mathrm{l}$ & 29.1 & $34-81$ & N.A. & N.A. \\
\hline
\end{tabular}

Source: Agamuthu, 2001 
Figure 1(a) shows that the optimum concentration of $\mathrm{FeCl}_{3}$ was $2 \mathrm{~g} / 500 \mathrm{~mL}$. Removal of turbidity was about $75 \%$, while the removal of colour and TSS was $70 \%$ and $78 \%$, respectively. However the removal of $\mathrm{Cd}, \mathrm{Pb}$, and $\mathrm{Cu}$ was $100 \%$ using $\mathrm{FeCl}_{3}$ while the $\mathrm{Zn}$ removal was $91 \%$. The optimum concentration for P-Floc775 was $2 \mathrm{~mL} / 500 \mathrm{~mL}$ (Figure 1b). Removal of turbidity, colour and TSS were $71 \%, 66 \%$ and $67 \%$ respectively while the removal of $\mathrm{Cd}$ and $\mathrm{Cu}$ was !00\% while $\mathrm{Pb}$ and $\mathrm{Zn}$ was $89 \%$ and $87 \%$, respectively.

Figure 1. (a)

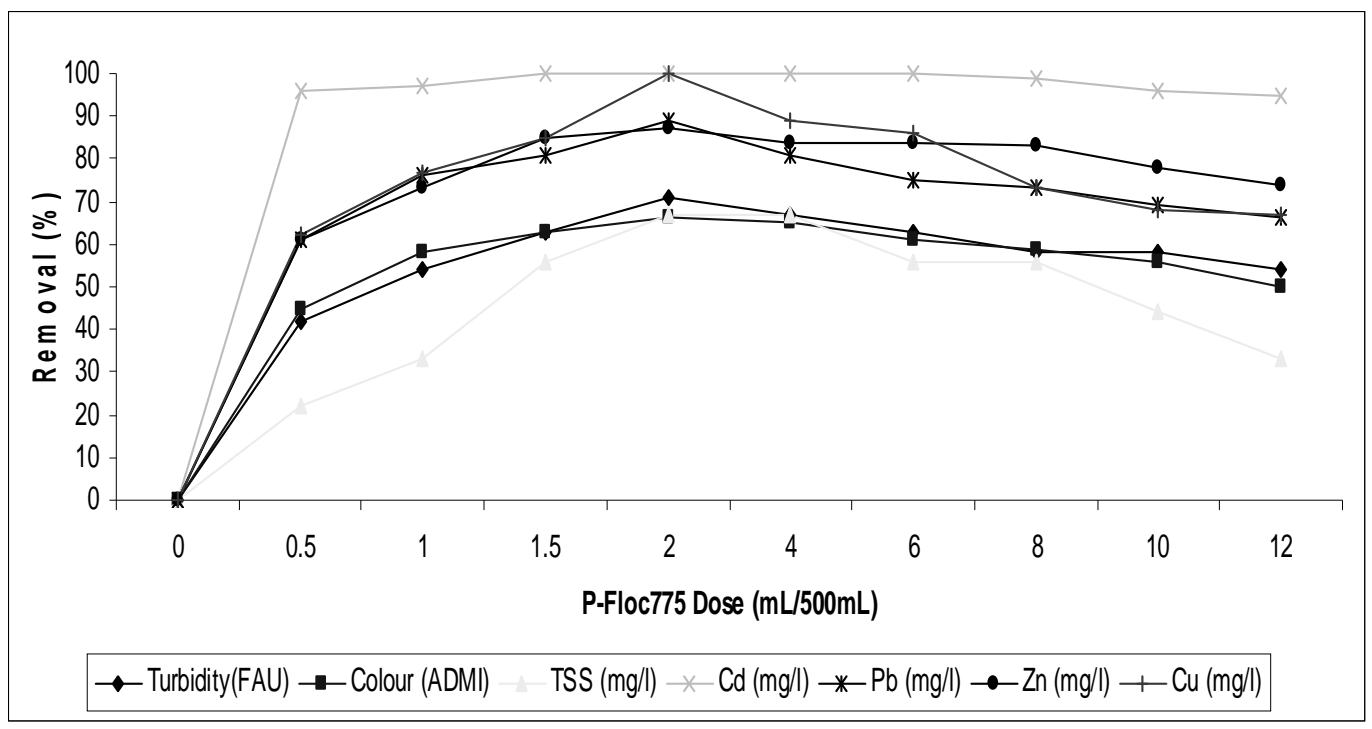

Figure 1. (b)

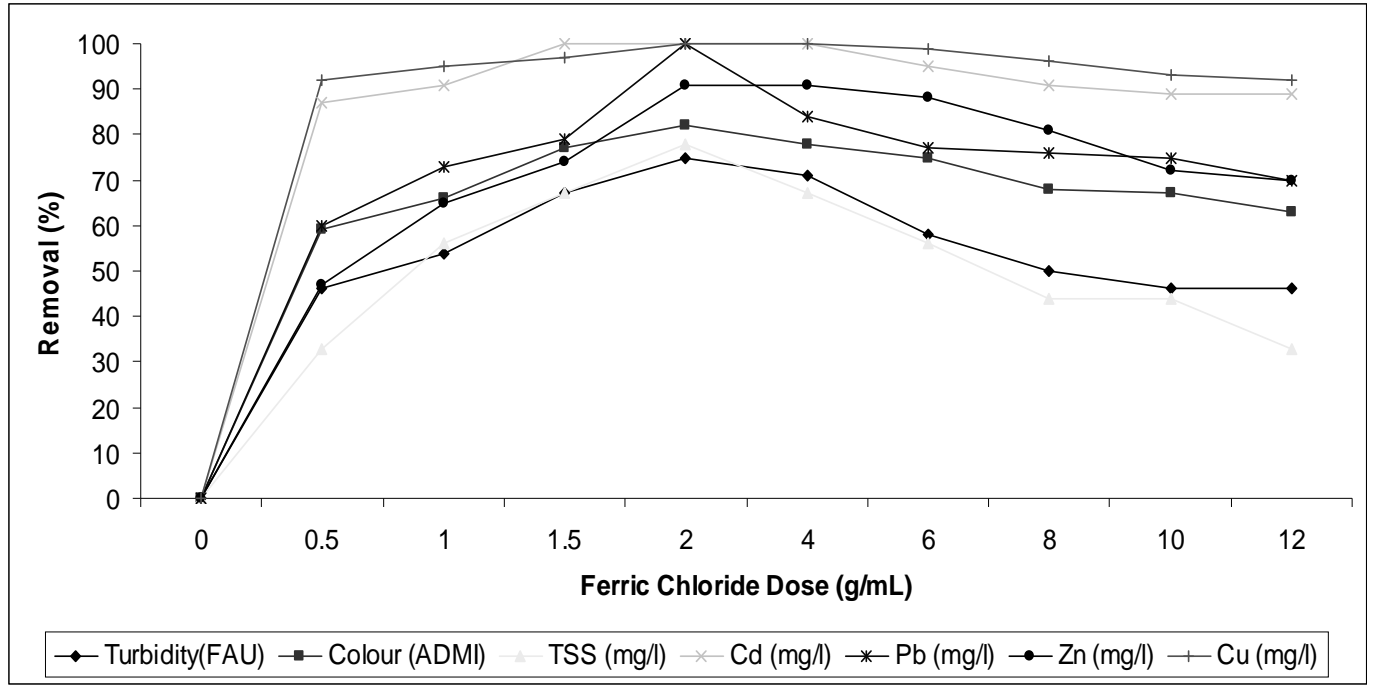


Study by Hamidi et al., [22] found that the removal of all parameters increased with increased dosage of coagulant $(200 \mathrm{mg} / \mathrm{L}$ of $\mathrm{FeCl} 3$ ) such as the removal of colour, turbidity, and suspended solids. Similar research was performed by Kargi, and Pamukoglu, [16], who reported that the best removal capacities for TSS was up to $80 \%$ at $1.5 \mathrm{~g} / \mathrm{L}$ (without $\mathrm{pH}$ adjustment) when coagulant were added to stabilized leachate. However, Nor Asikir and Agamuthu, [2] stated that $\mathrm{FeCl}_{3}$ was able to remove $85 \%$ of $\mathrm{Pb}, 88 \%$ of $\mathrm{Cu}, 90 \%$ of $\mathrm{Al}$, and $92 \%$ of $\mathrm{Zn}$ at the optimum dosage of was $4 \mathrm{~g} /$ $500 \mathrm{~mL}$. Also, Jayabala, [23], who used $\mathrm{FeCl}_{3}$, reposted the reduction of $\mathrm{Cd}$ at $83.3 \%$ at 60 $\mathrm{mg} / \mathrm{L}$. these findings tally with the range of reduction reported in this research.

Figure 2 ( $\mathrm{a}$ and $\mathrm{b}$ ) show the effect of $\mathrm{pH}$ on various parameters after treatment with $\mathrm{FeCl}_{3}$ and P-Floc775. The maximum removal of pollutants using $\mathrm{FeCl}_{3}$ and $\mathrm{P}-\mathrm{Floc} 775$ was at $\mathrm{pH}$ 7. The finding of this study is similar to the finding by Nor Asikir and Agamuthu, [2] who established that the optimum $\mathrm{pH}$ in reducing pollutants by $\mathrm{FeCl}_{3}$ was 7 . Ferric chloride was able to remove $97 \%$ of $\mathrm{Pb}, 90 \%$ of $\mathrm{Cu}, 82 \%$ of $\mathrm{Al}$, and $80 \%$ of Fe. Jayabala [23] found that Ferric chloride reduced $94 \%$ of Cd, 99.8 of As, and $94 \%$ of $\mathrm{Fe}$ at $\mathrm{pH} 6$. However, Tatsi et al., (2003) [16] found that the color removal was almost $100 \%$, during the addition of ferric chloride to stabilized leachate, especially when $\mathrm{pH}$ was adjusted at 10 . Slightly lower efficiencies (up to 93\%) were measured for fresh leachate samples, while Letterman et al., [24], stated that the optimal $\mathrm{pH}$ is dependent on the leachate characteristics, and it is normally 79 for $\mathrm{FeCl}_{3}$.

Figure 2. (a)

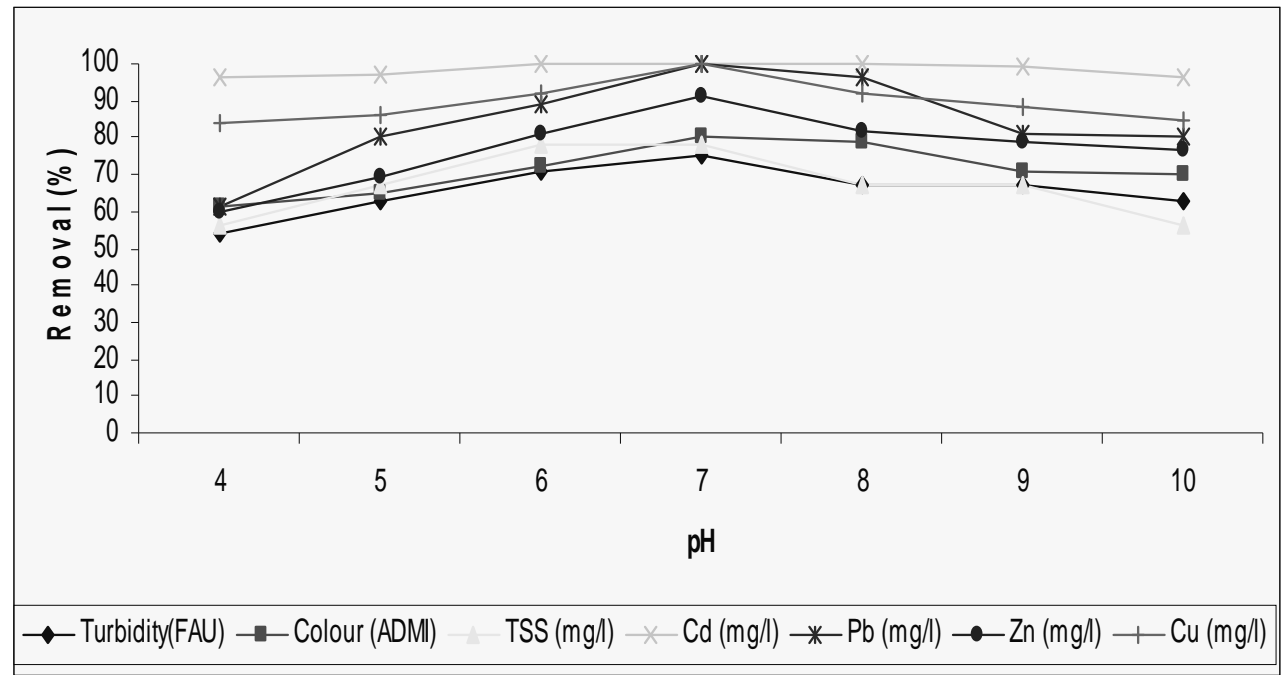

Figure2. (b)

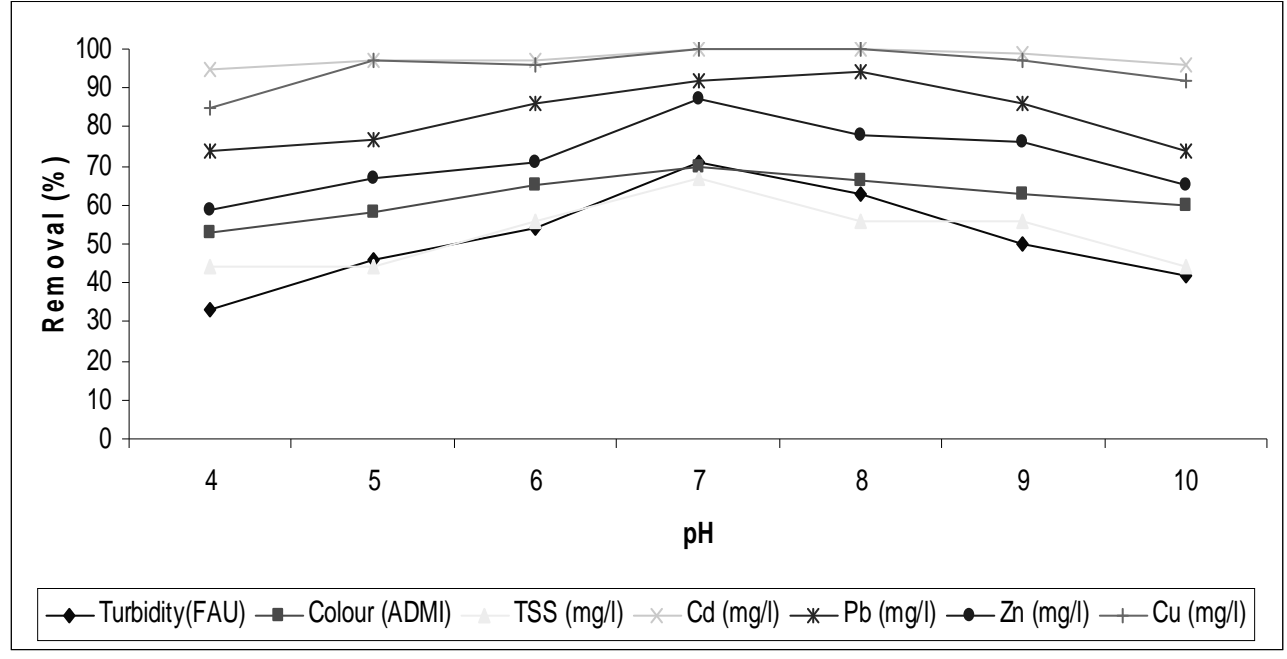


The effects of mixing speed ranging between 60 - $110 \mathrm{rpm}$ are given in Figures $3 \mathrm{a}$ and $3 \mathrm{~b}$. The optimum mixing speed for removal of pollutants using $\mathrm{FeCl}_{3}$ was $100 \mathrm{rpm}$ while the optimum mixing speed for P-Floc775 was $90 \mathrm{rpm}$. Rapid mixing ensures the total mixing of the coagulant in the solution whereas slow mixing cause the agglomeration of the flocs produced during the rapid mixing [2]. Nor Askir and Agamuthu, [2], established that $\mathrm{FeCl}_{3}$ was able to reduce about $78 \%$ of $\mathrm{Pb}, 80 \%$ of $\mathrm{Cu}, 74 \%$ of $\mathrm{Zn}, 70 \%$ of $\mathrm{Fe}$ and $80 \%$ of $\mathrm{Al}$, at mixing speed of $40-50 \mathrm{rpm}$, as compared to $\mathrm{FeCl}_{3}$ in this research which reduced $100 \% \mathrm{~Pb}, 89 \% \mathrm{Zn}$, and $100 \%$ of $\mathrm{Cu}$. $\mathrm{FeCl}_{3}$ removal in this study was more efficient, probably due to differences in the leachate composition.

Comparative optimum conditions for the removal of pollutants in terms of concentration, $\mathrm{pH}$ and mixing speed for each chemical are shown in Table 3. The pollutant removal efficiency for the parameter studied are also summarized for comparison.

Figure 3. (a)

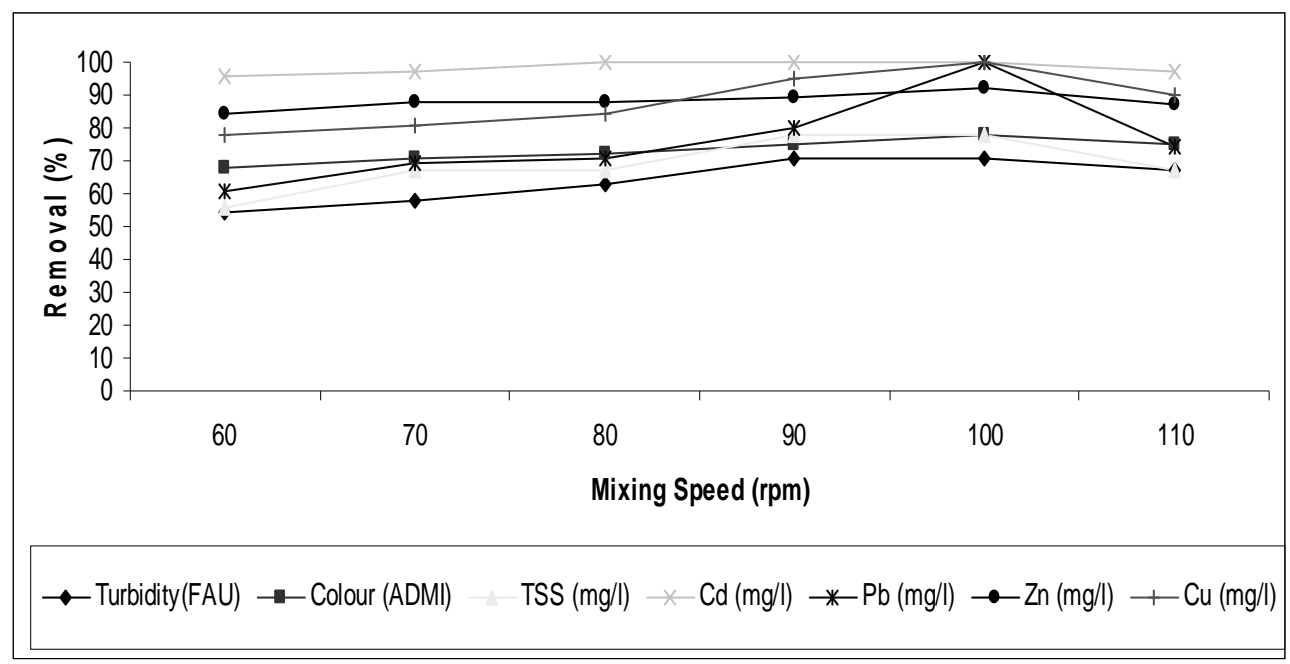

Figure 3. (b)

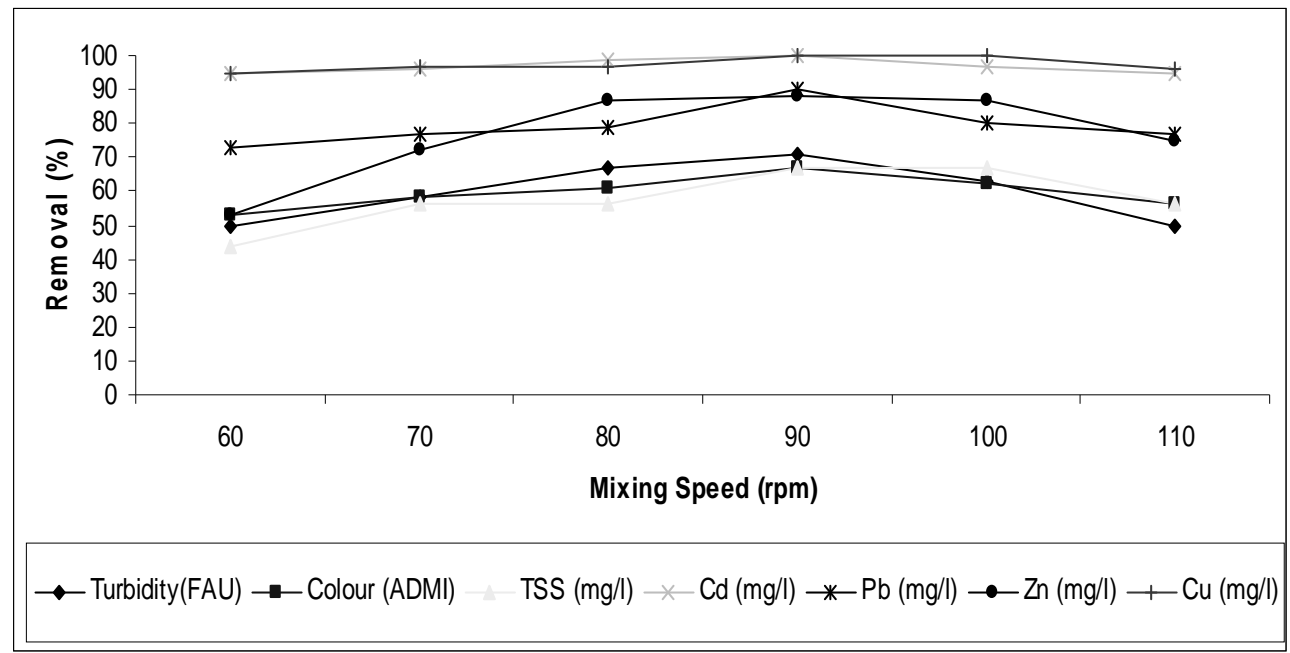


Table 3. Comparative removal of pollutants by each coagulant/flocculant at optimum conditions

\begin{tabular}{|c|c|c|c|c|c|c|c|c|}
\hline \multirow{2}{*}{\multicolumn{2}{|c|}{$\begin{array}{l}\text { Chemical \& Parameters } \\
\text { Optimal Condition }\end{array}$}} & \multicolumn{7}{|c|}{ \% removal } \\
\hline & & Turbidity & Colour & TSS & Cd & $\mathbf{P b}$ & Zn & $\mathbf{C u}$ \\
\hline \multirow{3}{*}{$\begin{array}{l}\text { P-Floc } \\
775\end{array}$} & $\begin{array}{l}\text { Concentration } \\
2 \mathrm{~mL} / 500 \mathrm{~mL}\end{array}$ & 71 & 66 & 67 & 100 & 89 & 87 & 100 \\
\hline & $\mathrm{pH} 7$ & 71 & 70 & 67 & 100 & 92 & 87 & 100 \\
\hline & $\begin{array}{l}\text { Mixing speed } \\
\text { 90rpm }\end{array}$ & 71 & 67 & 67 & 100 & 90 & 88 & 100 \\
\hline \multirow{3}{*}{$\begin{array}{l}\text { Ferric } \\
\text { chloride }\end{array}$} & $\begin{array}{l}\text { Concentration } \\
2 \mathrm{~g} / 500 \mathrm{~mL}\end{array}$ & 75 & 82 & 78 & 100 & 100 & 91 & 100 \\
\hline & pH 7 & 75 & 80 & 78 & 100 & 100 & 91 & 100 \\
\hline & $\begin{array}{l}\text { Mixing speed } \\
\text { 100rpm }\end{array}$ & 71 & 78 & 78 & 100 & 100 & 92 & 100 \\
\hline
\end{tabular}

\section{CONCLUSION}

Leachate from BTSL demonstrated high quantity of $\mathrm{COD}, \mathrm{BOD}, \mathrm{NH}_{3}-\mathrm{N}$, and heavy metals such as $\mathrm{Cd}, \mathrm{Pb}, \mathrm{Zn}$, and $\mathrm{Cu}$. All the parameters examined were above the EQA 1974 (Standard A and B) limit. Two coagulants/flocculants $\left(\mathrm{FeCl}_{3}\right.$, and $\mathrm{P}$ Floc775) were able to reduce heavy metal concentration from leachate. In general, $\mathrm{FeCl}_{3}$ was the most effective coagulant. $\mathrm{FeCl}_{3}$ performed optimum at $2 \mathrm{~g} / 500 \mathrm{ml}, \mathrm{pH} 7$ and $100 \mathrm{rpm}$ mixing speed while the optimum reduction by P-Floc775 was at $2 \mathrm{ml} / 500 \mathrm{ml}, \mathrm{pH} 7$ and $90 \mathrm{rpm}$ mixing speed. However after treatment by both coagulants/ flocculants some parameters still exceeded the requirements of Standard A and B of the EQA [24], hence it needs further treatment as is being implemented, to meet the Malaysian Standards requirements.

\section{ACKNOWLEDGEMENTS}

We wish to thank Bukit Tagar landfill management for the leachate samples. Funding was provided by University of Malaya (UM) through PJP (PS338/2007B).

\section{REFERENCES}

1. Fauziah S.H., and Agamuthu P., (2005). Pollution Impact of MSW Landfill Leacheate. Malaysian Journal of Science, 24(1): 31-37.

2. Nor Asikir M. and Agamuthu P. (2007), Characteristics and chemical treatment of Taman Beringin landfill leachate. Malysian J. of Science, 26 (1): 35-42

3. Agamutu, P., Fauziah SH and Kahlil Khidzir (2009). Evalution of Solid Waste Management in Malaysia: Impacts and Implications of the Solid Waste Bill 2007. J.Material cycles and Waste Management II (2).inpress.

4. Tatsi A.A., Zouhoulis A.I., (2002), A field investigation of the quantity and quality of leachate from a municipal solid waste landfill in a Mediterranean climate ( Theeealoniki, Greece) Adv. Environmental. Res.,6 (3): $207-$ 219.

5. Wang Z.P., Zhang Z., Lin Y-J., Deng N.S., Tao T., Zhuo K., (2002), Landfill leachate pre-treatment by a coagulation - photo oxidation process. J. hazard Mater. 95 (1-2): $153-159$.

6. Daekeun Kim, Hong - Duck Ryu, Man - Soo Kim, Jinhyeong Kim, and Sang - I11 Lee, (2007). Enhancing struvite precipitation potential for ammonia nitrogen removal in municipal landfill leachate. Journal of Hazardous materials 146: 81 - 85.

7. Ntampou X., Zouboulis A.I. and Samaras P., (2006). .Appropriate combination of physico-chemical methods 
(coagulation/flocculation and ozonation) for the efficient treatment of landfill leachates, Chemosphere, 62 (5):722-730

8. Adelaida Cabeza, Ane Urtiaga, Maria - Jose Rivero and Inmaculada Ortiz, (2007). Ammonium removal from landfill leachate by anodic oxidation. Journal of hazardous materials 144: 715 - 719 .

9. Aziz, H. A., Alias, S., Adlan, M. N., Faridah Asaari, A. H., and Zahari, M. S., (2007). Colour removal from landfill leachate by coagulation and flocculation processes. Bioresource Technology, 98: 218 - 220.

10. Ahn, W. Y., Kang, M. S., Yim, S. K., Choi, K. H., (2002). Advanced landfill leachate treatment using an integrated membrane processes. Desalination, 149(1-3): 109 - 114.

11. Rivas, F. J., Beltran, F., Gimeno, O., Acedo, B., and Carvalho, F., (2003). Stabilized leachate: Ozone - activated carbon treatment and kinetics. Water Resources, 37: 4823 4834.

12. Turan, M., Gulsen, H., Celik, M. S., (2005). Treatment of landfill leachate by a combined anaerobic fluidized bed and zeolite column system. Journal of Environmental Engineering ASCE, 131(5): 815 - 819.

13. Heyer, K.U., and Stegman, R., (2000). Landfill System, Sanitary Landfill of Solid Wastes Long - Term Problems with Leachate. In: Environment Process III-Solid Waste and Waste Gas Treatment, Preparation of Drinking Water [eds] J. Klein. J., winter. J., Wiley-VCH, Weinheim, 167-190.

14. Izzet Ozturk, Mahmut Altinbas, Ismail Koyuncu, Osman Arikan, and Cigdem Gomec - Yangin, (2003). Advanced physico - chemical treatment experiences on young municipal landfill leachates. Waste Management, 23: 441 - 446.

15. Tonni A.K., Lo W.Y., Chan G.Y., (2005), Physico-chemical treatments for removal of recalcitrant contaminants from landfill leachate, J. of Hazardous materials, 129 (1-3): 80-100.

16. Tatsi A.A., Zouboulis A.I., Matis K.A., Samaras P., (2003). Coagulation-flocculation pretreatment of sanitary landfill leachate. Chemospher, 53 (7):734-744.

17. Kargi, F., and Pamukoglu, (2003). Powdered activated carbon added biological treatment of pre-treated landfill leachate in a fed-batch reactor. Biotechnol. Lett. 25: 695 - 699.

18. Ayoub, G. M., Semerjian, L., Acra, A., El Fadel, M., Koopman, B., (2001). Heavy metal removal by coagulation with seawater liquid bittern, J. Environ. Eng. 127: 196 - 202.

19. Robinson, H.D., (1989). Development of methanogenic condition within landfill. Paper presented at Sardinia 1989: Second International Waste Management and Landfill Symposium, Porto Coute, Sardinia, Italy: 913, October 1989.

20. Environmental Quality Act 1974 (Act 127) and Subsidiary Legislations, Amendment 5 (May 2007). International Law Book Service, Kuala Lumpur.

21. Accot Technologies Sdn. Bhd, (2008). Available from http://www.accot.biz.

22. Hamidi Abdul Aziz, Salina Alias, Mohd. Nordin Adlan, Faridah, A.H. Asaari, Mohd. Shahrir Zahari, (2007). Colour removal from landfill leachate by coagulation and flocculation processes, J. of Bioresource Technology 98: 218-220

23. Jayabala M., M. (2005). Removal of arsenic from municipal landfill leachate. Dissertation M. Tech. (Environmental Mgmt.) Institute of Biological Sciences, University of Malaya. 145 pp.

24. Letterman, R., D., Amirtharajah, A and O'Melia, C.R. (1998). Coagulation and Flocculation in water quality and treatment. $5^{\text {th }}$ edition. McGraw-hill, New York. 166 pp. 
Malaysian Journal of Science 28 (2): 187 - 195 (2009) 